\title{
Cellulose nanostructured films from pretreated açai mesocarp fibers: physical, barrier, and tensile performance
}

Dayse Gonzaga Braga ${ }^{1 \mathrm{iD}}$, Juliana Livian Lima de Abreu ${ }^{1 \mathrm{iD}}$, Marcela Gomes da Silva ${ }^{1 \mathrm{iD}}$, Tiago Marcolino de Souza ${ }^{2 \mathrm{iD}}$, Matheus Cordazzo Dias ${ }^{3 i D}$, Gustavo Henrique Denzin Tonoli3iD, Cândido Ferreira de Oliveira Neto ${ }^{1 \mathrm{iD}}$, Pedro Ivo Cunha Claro ${ }^{4 i D}$, Laércio Gouvêa Gomes ${ }^{5 i D}$, Lina Bufalino* 1id

${ }^{1}$ Rural Federal University of Amazônia, Belém, Brazil

${ }^{2}$ State University of Amapá, Macapá, Brazil

${ }^{3}$ Federal University of Lavras, Lavras, Brazil

${ }^{4}$ Federal University of São Carlos, São Carlos, Brazil ${ }^{5}$ Federal Institute of Pará, Belém, Brazil

\section{TECHNOLOGY OF FOREST PRODUCTS}

\section{ABSTRACT}

Background: During de-pulping of açai (Euterpe oleracea) for juice production in the Amazonia, large amounts of fibrous waste are daily discarded, a promising substrate for production of high-value cellulose nanofibrils. Therefore, this study sought to evaluate the modifications of açai surface fibers submitted to chemical pretreatment steps and compare the quality of nanostructured films produced with different cycles of mechanical nanofibrillation.

Results: A 2-hour pretreatment (at $5 \%$ of $\mathrm{NaOH}$ ) followed by two $\mathrm{NaOH} / \mathrm{H}_{2} \mathrm{O}_{2}$, bleaching steps resulted in fibers with increased length and reduced diameter compared to raw fibers while preserving fiber integrity and cellulose I structure. The increase of fibers' grinding cycles from 3 (minimum to gel point) to 21 (maximum suspension thickness) resulted in nanofibril films with higher crystallinity properties, uniform thickness, compacted morphology, and smoother surface. Nanofibril films formed after different numbers of passages exhibited similar mechanical strength, but distinct barrier properties.

Conclusion: Açaí waste films produced with fibers submitted to 3 grinding cycles can be recommended for packaging applications that demand easily dissolving, such as instantaneous food. Oppositely, açaí fibers subjected to 21 cycles in grinder provide films suitable for water-resistant packaging, ideal for secondary coatings of papers and paperboards.

Keywords: Alkaline pretreatment, Bleaching steps, Crystalline index, Barrier properties, Packaging

\section{HIGHLIGHTS}

Açaí waste contains short and handily removable lignocellulosic fibers.

Pretreatments raise crystalline index, individualize and clean açaí fibers.

3-grinder-passages nanofibrils form films applicable for easily dissolving packaging.

21-grinder-passages nanofibrils form films applicable for barrier resistant packaging.

BRAGA, D. G.; ABREU, J. L.L.; SILVA, M. G. S.; SOUZA, T. M. S.; DIAS, M. C.; TONOLI, G. H. D.; OLIVEIRA NETO, C.O. FERREIRA; CLARO, P. I. C.; GOMES, L. G.; BUFALINO, L. Cellulose nanostructured films from pretreated açai mesocarp fibers: physical, barrier, and tensile performance China. CERNE, v. 27, e-102783, doi: 10.1590/01047760202127012783 


\section{INTRODUCTION}

The Euterpe oleracea Mart. palm, commonly known as açaizeiro, produces bunches with many açai edible fruits (Santos et al., 2019). The pulp of this fruit is vital to the economic, social, and cultural contexts of the Amazonian region, where it is incorporated into typical gastronomy. The ubiquitous nature of these berries within the region has even resulted in açai-centric tourism (Santana et al., 2014). In 2018, 147,730 t of açai were extracted within the Pará state, the foremost producer and consumer of this fruit in the world (IBGE, 2020). In local markets, electric de-pulping machines are used to separate the edible pulp from the waste fraction through friction and the addition of water (Santana et al., 2014). The discarded de-pulping waste accounts for nearly $81 \%$ of the total mass processed (Bufalino et al., 2018), meaning that 119,661 t of waste were produced in 2018 by the Pará state alone. Surface fibers comprise about 3 wt.\% of the açai waste (Bufalino et al., 2018), indicating that approximately 3,590 t of cellulose-rich feedstock were available in the same year.

In the Amazonian region, urban and rural populations alike consume açai pulp daily, creating a demand that ensures continuous waste production throughout the year. The residues accumulate near the production centers or in large waste deposits, causing land pollution problems as well as in nearby river systems (Maranho and Paiva, 2011). Therefore, the local population's quality of life could be markedly improved by the consumption and sale of açai wastes for bioenergy or other industries (Bufalino et al., 2018). The surface fibers of the açai waste are easily removed by hand, creating a promising opportunity for their use in the production of valuable biomaterials (Oliveira et al., 2019).

Natural fibers are biodegradable, non-abrasive, economical, present low density, and have high specific properties (Saheb and Jog, 1999). Furthermore, they are highly variable and can be sourced from many different plants (Khanam et al., 2007) across several geographical locations. They can be used to produce papers (Sharma et al., 2019), useful chemicals (Naeimi et al., 2018), fuels (Bufalino et al., 2018; Naiemi et al., 2018; Protásio et al., 2013), and composites materials applicable to the automobile and construction industries (Khanam et al., 2007; Bongarde and Shinde, 2014; Mesquita et al., 2018; Shulga et al., 2019). However, fiber performance on the microscale and the necessity of fibers' pretreatments has limited their application continuously in the biomaterial field, which mandates alteration of morphological, chemical, and physical properties (Shulga et al., 2019). A possible solution is their utilization in the nanoscale, adding value to the feedstock and bringing many powerful benefits to highly advanced applications, such as smaller dimensionality and increased surface area (Syverud and Stenius, 2009).

Alkalization and bleaching are the most common pretreatments for the removal of non-cellulosic components from naturally fibrous materials. These processes must occur before their conversion to micro/nanofibrils (Fonseca et al., 2019). If the pretreatments did not accomplish a satisfactory level, fibers might be morphologically damaged and chemically degraded (Corrêa et al., 2010; Bufalino et al.,
2014; Bufalino et al., 2014). The intrinsic characteristics of each fiber type demand adjustments in the pretreatment conditions (solvent level, reaction temperature and time, etc.), as starting fibers of low-quality result in low-quality nanofibrils (Bufalino et al., 2014; Bufalino et al., 2014; Scatolino et al., 2017; Scatolino et al., 2017; Fraga and Tavares, 2017; Oliveira et al., 2019; Fonseca et al., 2019).

After cellulose isolation, the pretreated fibers may be converted into cellulose nanofibrils. These nanofibrils consist of long nanometric structures with amorphous and crystalline alternating regions, which are extracted from the fibers cell wall by intense mechanical refining (Syverud et al., 2011; Nechyporchuk et al., 2016). Nanofibrils may be used to form films by the simple "casting" technique, which can be applied in food conservation, seed coatings, packaging materials, automotive industry, domestic products, paper-substrate, and electronic devices (Syverud and Stenius, 2009; Syverud et al., 2011). The influence of fiber nanofibrillation on film quality and, consequently, its applicability has already been attested in previous research (Bufalino et al., 2015a; Scatolino et al., 2017).

The production of cellulose micro/nanofibrils has been studied using different wood (Syverud et al., 2011; Fonseca et al., 2016; Scatolino et al., 2017; Scatolino et al., 2017; Dias et al., 2019; Bufalino et al., 2015a) and non-wood feedstock, such as sugarcane bagasse, rice straw (Hassan et al., 2012), hemp, flax, bast (Alila et al., 2013; Panthapulakkal and Sain, 2013), jute (Alila et al., 2013), sisal and abaca leaves (Alila et al., 2013), banana rachis (Zuluaga et al., 2009), bamboo (Guimarães Júnior et al., 2015), aloe vera (Kakroodi et al., 2014), curaua (Côrrea et al., 2010), and cocoa shell (Souza et al., 2019).

Previous research reported that açai fibers exhibit desirable thermal stability and have mechanical properties comparable to other natural fibers commonly used in the polymeric composites industry (Martins et al., 2008). The effect of açai fibers as a reinforcement material in recycled, conventional thermoplastics such as polystyrene (PS) and polypropylene (PP) was evaluated. Despite the poor interfacial adhesion between fiber and matrix, the addition of açai fibers enhanced the impact resistance of both polymers (Castro et al., 2010). Pretreatments of the açai mesocarp fibers with low levels of sodium hydroxide (5\% and $10 \%$ ) at $80^{\circ} \mathrm{C}$ and $100^{\circ} \mathrm{C}$ increased the material's crystalline index, reduced the fi diameter and nonlignocellulosic components significantly, and exposed the inner lignin (Oliveira et al., 2019).

To the extent of the authors' current knowledge, açai mesocarp fibers have not yet been utilized for the production of cellulose nanofibril films for packaging. Two hypotheses were raised: 1) açaí mesocarp fibers progressively modify by typical chemical pretreatments allowing further mechanical nanofibrillation; and 2) the fibers would be versatile enough to provide packaging films for different applications by adjusting the nanofibrillation level, i.e., the number of passages in a grinder. Therefore, this study sought to evaluate the modifications of açai surface fibers submitted to chemical pretreatment steps and to compare the mechanical and barrier performance 
of nanostructured films produced with different cycles of mechanical nanofibrillation.

\section{MATERIAL AND METHODS}

\section{Materials}

The reagents used in the experimental assays were sodium hydroxide P.A. (98\%, Dinâmica, Brazil), hydrogen peroxide P.A. (35\%, Dinâmica, Brazil), hydroalcoholic safranin P.A. (1\%, Dinâmica, Brazil), and glycerine P.A. (100\%, Dinâmica, Brazil).

Fruit-containing bunches were collected from $E$. oleracea Mart. palms (Figures 1a and 1b). A local producer in São Miguel do Guamá (Latitude: $1^{\circ} 37^{\prime}$ 40" South; Longitude: $47^{\circ} 28^{\prime} 55^{\prime \prime}$ West), located in the Pará Amazon state, Brazil, processed the açai fruits (Figure 1c) using an electric beater (Figures 1d and 1e) to obtain the pulp (Figure 1f) and de-pulping waste (Figure 1g). The açai waste was continuously washed to remove pulp traces (Figure $1 \mathrm{~h}$ ) and dried at room conditions $\left(\sim 27^{\circ} \mathrm{C}\right.$ and $\left.83 \% \mathrm{RH}\right)$. The cleaned açai waste, composed of seeds covered by lignocellulosic fibers, was processed to separate the fibers from the surface of the seeds (Figure 1i).
Pretreatments of açai fibers, nanofibrillation, and production of nanostructured films

Prior to pretreatments, the fibers were immersed in distilled water for $24 \mathrm{~h}$. Fibers were weighed before and after each pretreatment to allow yield calculation. Dry basis moisture content was determined using about $2 \mathrm{~g}$ of fibers for each condition in order to estimate moisture-free fiber mass before and after pretreatments. The alkali pretreatment was carried out with fiber to solution proportion of 1/100 (w/w), in a sodium hydroxide aqueous solution at $5 \%(\mathrm{w} / \mathrm{w})$ under mechanical stirring ( $500 \mathrm{rpm}$ ). The reaction temperature of $80^{\circ} \mathrm{C}$ was reached and maintained for $2 \mathrm{~h}$. The fibers were washed with distilled water until a neutral $\mathrm{pH}$ was reached. Water excess was manually removed, and fibers kept inside plastic bags under vacuum to be stored in the refrigerator.

Before bleaching, pretreated alkaline fibers were kept in water until saturation and then vigorously stirred at $18,000 \mathrm{rpm}$ to increase chemical attack efficiency. An aqueous solution of $\mathrm{NaOH}$ at $4 \%$ and $\mathrm{H}_{2} \mathrm{O}_{2}$ at $24 \%$ with a 1:1 (v:v) ratio was prepared. The pretreated alkali fibers were added at $1 \mathrm{~g}$ to $80 \mathrm{~mL}$ of solution. The bleaching process was carried out at $60{ }^{\circ} \mathrm{C}$ throughout $2 \mathrm{~h}$ for the first step (Bc_1x2h) and then $3 \mathrm{~h}$ for the second one (Bc_2x3h), both
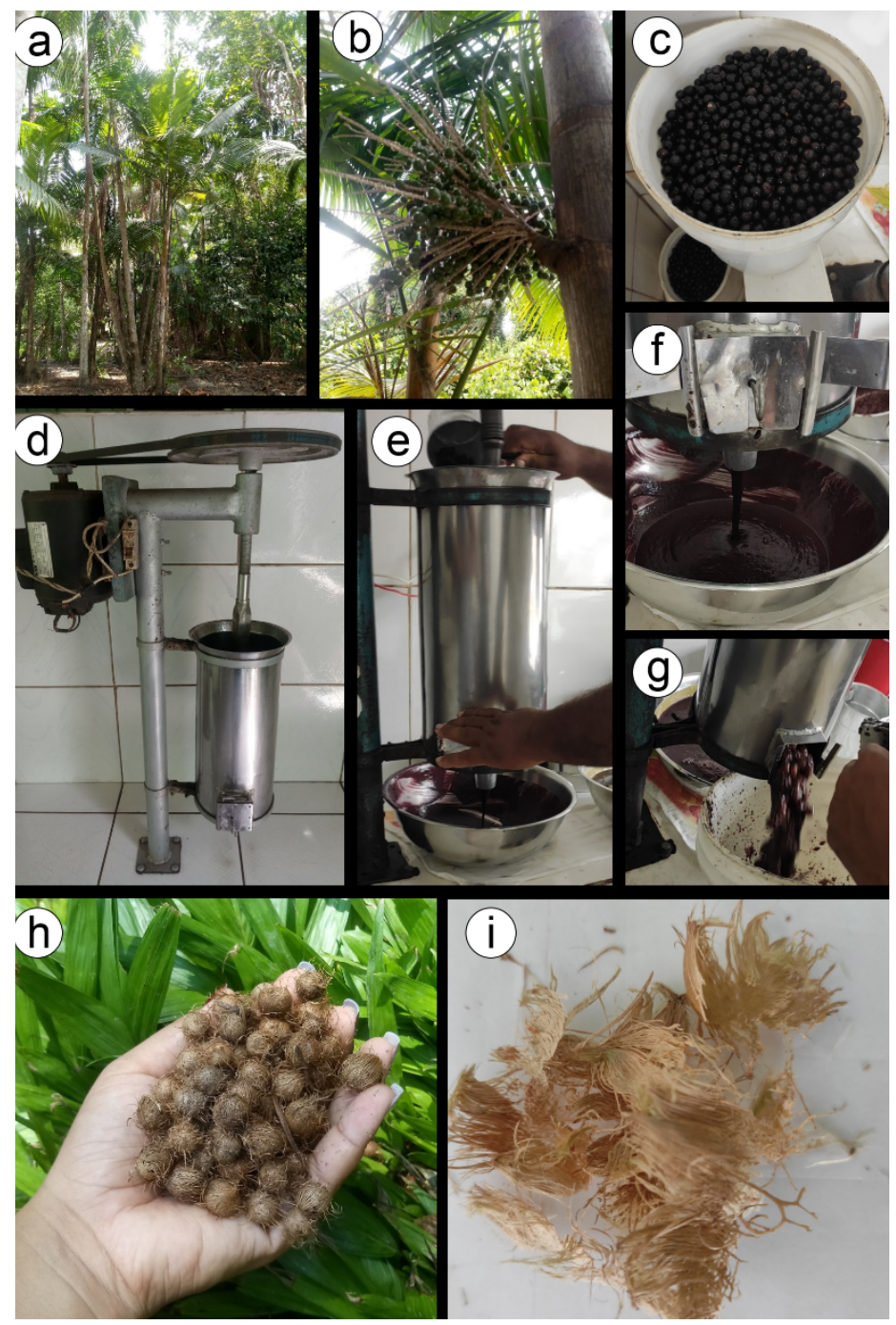

Fig. 1 Açai from the forest to urban waste: a) açai palm; b) fruit bunch; c) mature fruit; d) depulping machine; e) depulping processing; f) edible pulp; g) waste generation; h) clean waste (seeds + surface lignocellulosic fibers); and i) waste mesocarp fibers handily removed from the seeds, the studied feedstock. 
with mechanical stirring at 4,000 rpm. After bleaching, fibers were washed with distilled water until the filtering solution reach a neutral $\mathrm{pH}$. Bleached fibers were dried at $50{ }^{\circ} \mathrm{C}$ for $48 \mathrm{~h}$.

The bleached fibers were immersed in 1,557 $\mathrm{mL}$ of distilled water (accounting for fiber moisture content) at $1.5 \%(\mathrm{w} / \mathrm{v})$ proportion. Fibers were kept immersed in water for $72 \mathrm{~h}$ in order to facilitate swelling of the cell walls (Dias et al., 2019). Every 24 h, the fiber suspension was submitted to mechanical stirring at $700 \mathrm{rpm}$ for $30 \mathrm{~min}$. An additional stirring operation was performed immediately before nanofibrillation. Cellulose nanofibrils were obtained using a mechanical nanofibrillator, often referred to as a grinder, (Supermasscolloider model MKCA6-2 J, Masuko Sangyo Co. Ltd. ${ }^{\circledR}$, Japan) at 1,500 rpm (Tonoli et al., 2016; Scatolino et al., 2017; Dias et., 2019). The gap between the aluminum oxide stones in the grinder was adjusted to $\pm 50 \mu \mathrm{m}$, and the electric current was maintained at $6 \mathrm{~A}$. The minimum number of cycles in the grinder that produced a suspension that formed films was three (3), and energy expenditure was $1.24 \mathrm{kWh} /$ $\mathrm{kg}$. The maximum number of cycles until the suspension was too thick and the grinder could not process it anymore was 21 (Iwamoto et al., 2007) with an energy expenditure of $12.60 \mathrm{kWh} / \mathrm{kg}$. Films formed by the maximum, and the minimum number of passages were compared.

Films were formed by casting method using nanofibrils collected after 3 and 21 cycles in the grinder. Nanofibril suspensions aliquots of $20 \mathrm{~mL}$ were deposited on $7 \mathrm{~cm}$-diameter acrylics Petri dishes and dried at $50^{\circ} \mathrm{C}$ for $24 \mathrm{~h}$. The entire methodology employed herein, from fiber preparation to nanofibril film formation and characterization, is summarized in Figure 2.

\section{Characterizations Fiber morphology}

Fibers were stained in a solution containing 5 $\mathrm{mL}$ of distilled water, $1 \mathrm{~mL}$ of glycerin, and four drops of hydroalcoholic safranin. Two microscope slides were prepared for each fiber condition (raw and pretreated).

The fibers' morphological traits were analyzed using an optical microscope (BA310E, MOTIC ${ }^{\circledR}$, Hong Kong). The fiber diameter and length were measured using the $4 \mathrm{x}$ objective lens and the Motic Images Plus software (MIP 3.0). For each fiber condition (raw, alkali-treated, or bleached), thirty measurements of fiber length and diameter were taken. Box plots were produced using Microsoft Excel in order to visualize sample population statistics, including the mean, median, and quartile ranges for both fiber length and diameter. The mean aspect ratio of the fibers was estimated by dividing the mean length by the mean diameter.

\section{X-ray diffraction}

The crystalline structure of the nanofibrils was analysed using a diffractometer (Model D2 Phaser, Bruker ${ }^{\circledR}$, Germany) with $\mathrm{Cu}-\mathrm{K} \alpha$ radiation $(\kappa=1.540 \AA)$ and nickel filter, operating at $30 \mathrm{kV}$ and $10 \mathrm{~mA}$. The samples were evaluated with $\theta$ ranging from $5^{\circ}$ to $55^{\circ}$.

The crystalline indexes $(\mathrm{Cl})$ of samples were obtained using the software Magic Plot Student after the raw data filtering for the determination of the crystalline and amorphous fractions by area calculations. The $\mathrm{Cl}$ was calculated using Eq. 1 proposed by Segal et al. (1959). Where $\mathrm{Cl}$ is the crystalline index (\%), 1200 is the maximum intensity of the main diffraction peak $\left(2 \theta=22.7^{\circ}\right.$ for cellulose । and $2 \theta=21.7^{\circ}$ for cellulose II), and lam is the intensity of

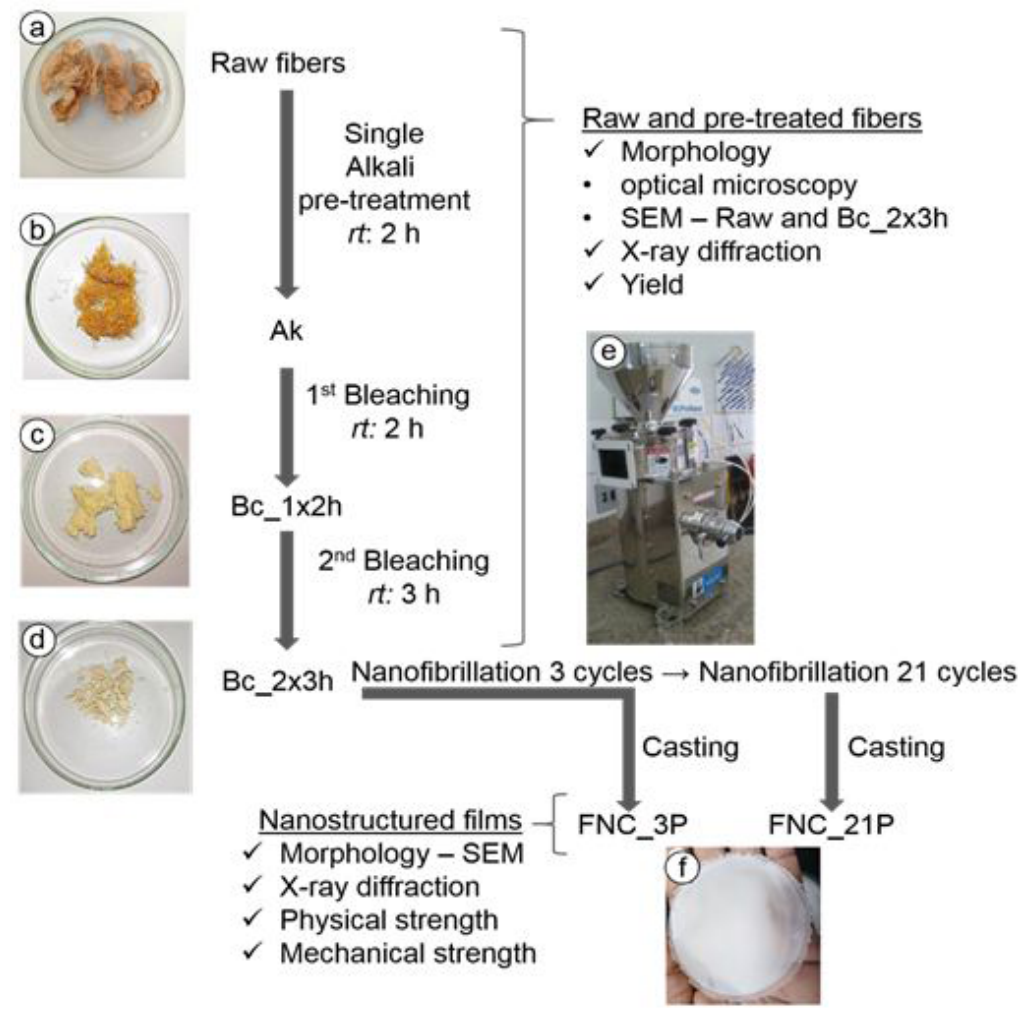

Fig. 2 Pretreatments, nanofibrillation, and production of nanostructured films. rt: reaction time; (a) raw fibers; (b) alkali pretreated fibers (Ak); (c) fibers after one bleaching step lasting 2 h (Bc_1x2h); (d) fibers after two bleaching steps, the first lasting 2 $\mathrm{h}$ and the second lasting $3 \mathrm{~h}$ (Bc_2x3h); (e) grinder; ( $f$ ) nanofibril film; and FNC_3P and FNC_21P - films formed after 3 and 21 cycles in the grinder, respectively. 


$$
C I=\left(\frac{1-\operatorname{Iam}}{I 200}\right) \cdot 100
$$

diffraction corresponding to only the amorphous material ( $2 \theta=18^{\circ}$ for cellulose I, and $2 \theta=16^{\circ}$ for cellulose II),

$$
\text { Crystallite size (CS) was determined }
$$
according to Eq. 2 (Langford and Wilson, 1978). Where CS is the size of the crystallite perpendicular to the structure represented in the (200) plane $(\AA), k$ is a shaperelated constant $(0.9), \lambda$ is the radiation wavelength $(1.54056 \AA), \beta$ is the mean width of crystalline peak related to (200) plane (rad), and $\theta$ is the position of the plane (200) $\operatorname{peak}\left(2 \theta=22.7^{\circ}\right)$.

$$
C S=\frac{k \lambda}{\beta \cos \theta}
$$

The width of a cellulose chain is $4 \AA$, but simply dividing the crystallite size by this number does not account for the whole crystallite. Therefore, Eq. 3 was used to estimate the number of cellulose chains (N) present in each crystallite (Ballesteros et al., 2017). Where $N$ is the number of cellulose

$$
N=\left(R \frac{1+\frac{C S}{4}}{2}\right)^{2}
$$

chains present in the crystallite, $\mathrm{R}$ is a rounding operator, and CS is the crystallite size perpendicular to the (200) plane $(\AA)$.

The nanofibril samples were assayed in the film condition, with a mean thickness of $0.041 \pm 0.003 \mathrm{~mm}$.

\section{Scanning electron microscopy (SEM) of the films}

SEM micrographs of the surface and sides of the films were obtained using a scanning electron microscope (TM3030PLUS model, HITACHI ${ }^{\circledR}$, Japan) with a voltage of $15 \mathrm{kV}$. The samples were placed on double-sided carbon adhesive tapes that were previously fixed on aluminum sample holders (stubs).

\section{Physical and barrier properties of the films}

Three specimens of each film group were cut with a $3 \mathrm{~cm}$ diameter after the previous drying at $70^{\circ} \mathrm{C}$ for 24 $\mathrm{h}$ and subsequent weighing. The water vapor absorption test was performed in a controlled environment at $19^{\circ} \mathrm{C}$ and $100 \% \mathrm{RH}$ inside a desiccator following ASTM E104-02 (2002). Samples were weighed after 1, 2, 3, 4, 5, and 24 h. Steady-state was said to be achieved when consecutive weighing did not demonstrate relevant absorption. Water vapor absorption (WVA) was estimated using Eq. 4. Where WVA is the water vapor absorption (\%), Mc is the current mass $(\mathrm{g})$, and $\mathrm{Mi}$ is the dry mass $(\mathrm{g})$.

$$
W V A=\left(\frac{M c-M i}{M i}\right) \cdot 100
$$

The water solubility (WS) of the films was determined, according to Gontard et al. (1994), using circular specimens with a diameter of $2 \mathrm{~cm}$. Triplicates were evaluated for each film type. The initial dry mass was obtained after drying at $55 \pm 2^{\circ} \mathrm{C}$ for $24 \mathrm{~h}$. The specimens were immersed in $40 \mathrm{~mL}$ of distilled water for $24 \mathrm{~h}$ at room temperature. The resulting suspensions were filtered, dried at $105^{\circ} \mathrm{C}$ for $24 \mathrm{~h}$, and weighed. The solubility of films was expressed as the percentage of solubilized mass concerning the initial mass and was calculated by Eq. 5 . Where WS is the solubility (\%), Ms is the non-solubilized mass (g), and Md is the dry mass ( $\mathrm{g}$ ).

$$
W S=\left(\frac{M d-M s}{M d}\right) \cdot 100
$$

Water vapor permeability rate and water vapor permeability of the films were both determined in duplicate using gravimetric parameters in accordance with ASTM E96-00 (2000) and literature (Bourtoom and Chinnan, 2008; Guimarães Júnior et al., 2015). Circular specimens with a diameter of $10.5 \mathrm{~mm}$ were cut using steel molds, dried in an oven at $150^{\circ} \mathrm{C}$ for $24 \mathrm{~h}$, and placed in amber glass with $3 / 4$ of its volume containing silica gel (desiccant) with a particle size ranging from 1 to $4 \mathrm{~mm}$. The containers had a top diameter of $15 \mathrm{~mm}$, a length of $58 \mathrm{~mm}$, and a base diameter of 26 $\mathrm{mm}$. The covers had a height and diameter of $18 \mathrm{~mm}$ and $20 \mathrm{~mm}$, respectively. They were perforated at the top with the same dimensions of the glass permeation area. The specimens were placed between the glass and cover.

The specimens were kept in an environment with zero water activity. The containers were placed in sealed desiccators at an environmental temperature of $30 \pm$ $2{ }^{\circ} \mathrm{C}$ and filled with $800 \mathrm{~mL}$ of water. This resulted in 0.1 atmospheric water activity in contact with the upper surface of the specimens. Mass gain measurements were conducted by weighing the specimens at a precision of $0.0001 \mathrm{~g}$ every $24 \mathrm{~h}$ for seven days.

The water vapor permeability rate (WVPR) of the films was estimated using linear regression between mass gain and time (24 h) per area, as showed below (Eq. 6). The slope of the linear part of the curve represented the amount of water vapor diffusion through the specimen per time unit. After determining the saturated pressure of water vapor (sp, Eq. 7), water vapor permeability (WVP) was calculated (Eq. 8). Where WVPR is the water vapor permeability rate $\left(\mathrm{g} \cdot \mathrm{h}^{-1} \cdot \mathrm{m}^{2}\right)$, $\mathrm{g} / \mathrm{T}$ is the slope of the line obtained by the linear regression of mass gain $(\mathrm{g})$ in relation to conditioning time $(\mathrm{h}), \mathrm{A}$ is the permeation area of each specimen $\left(\mathrm{m}^{2}\right), \mathrm{sp}$ is the saturated pressure of water vapor at the test temperature of $30^{\circ} \mathrm{C}$ $(\mathrm{KPa}), \mathrm{T}$ is the conditioning temperature $\left(20^{\circ} \mathrm{C}\right)$ of the desiccator containing cells with films and distilled water, WVP is the water vapor permeability $\left(\mathrm{g} \mathrm{mm} \mathrm{KPa}^{-1} \cdot \mathrm{day}^{-1} \cdot \mathrm{m}^{2}\right)$, $t$ is the thickness of the specimen $(\mathrm{mm}), \mathrm{RH}$ is the relative humidity inside the desiccator containing distilled water (100\%), and $\mathrm{RHi}$ is the relative humidity (\%) inside the glass containing white silica equals to $0 \%$.

$$
W V P R=\left(\frac{g}{T x A}\right) \cdot 100
$$

$s p=0.6108 \varepsilon^{\left(\frac{17.27 T}{T+237.3}\right)}$

$W V P=\frac{W V P t}{\left(\frac{s p R H}{100}-\frac{s p R H i}{100}\right)}$

The bulk density (BD) and basis weight (BW) of the films were determined using the mass (weighted with the precision of $0.0001 \mathrm{~g}$ ), and the volume achieved after drying at $100^{\circ} \mathrm{C}$ until no change in mass was observed. The thickness of the films was measured with ImageJ 
software utilizing SEM micrographs To obtain the volume. The film diameter was measured with a $0.1 \mathrm{~cm}$-precise ruler. The properties were calculated by Eq. 9 and 10 . Where BW is the basis weight, BD is the bulk density $\left(\mathrm{g} \mathrm{cm}^{-3}\right)$, $\mathrm{m}$ is the mass $(\mathrm{g}), A$ is the area $\left(\mathrm{m}^{2}\right)$, and $v$ is the volume $\left(\mathrm{cm}^{3}\right)$.

$$
\begin{aligned}
& B W=\frac{m}{A} \\
& B D=\frac{m}{v}
\end{aligned}
$$

\section{Tensile strength of films}

Mechanical strength tests were carried out using a universal testing machine (Model WDW 100E, AROTEC ${ }^{\circledR}$, China). Tests were performed following ASTM D882-12 (2012). The samples' nominal dimensions were $10 \pm 2 \mathrm{~mm}$ in width, $100 \pm 10 \mathrm{~mm}$ in length, and $0.10 \pm 0.08 \mathrm{~mm}$ in thickness. Six replicates of films were tested for each film produced. The distance between the jaws, the test velocity, and the maximum load were $80 \mathrm{~mm}, 0.5 \mathrm{~mm} \mathrm{~s}^{-1}$, and 196,133 $\mathrm{N}$, respectively. The Young's modulus (E) was determined using the stress-strain curves (Eq. 11). The maximum tensile strength $\left(\sigma_{\text {max }}\right)$ and strain $(\varepsilon)$ were calculated according to Eq. 12 and 13, respectively. Where $\sigma_{\max }$ is the maximum tensile strength (MPa), $F$ is the maximum force $(N), A$ is the specimen's initial area $\left(\mathrm{mm}^{2}\right)$, E is Young's modulus (MPa), $\sigma$ and $\mathrm{df}$ is the current tensile strength $(\mathrm{N})$ and deformation, respectively, $\mathcal{E}$ is the strain at break (\%), and $\mathrm{SI}$ and Si are the last strain and initial strain $(\mathrm{mm})$, respectively.

$$
\begin{aligned}
& E=\frac{\sigma}{d f} \\
& \sigma_{\max }=\frac{F}{A} \\
& \varepsilon=\left(\frac{S l-S i}{S i}\right) \cdot 100
\end{aligned}
$$

\section{RESULTS AND DISCUSSION}

\section{Morphological and crystalline modifications of the açai fibers by pretreatments}

The açai fiber morphology (length, diameter, and aspect ratio) changed with the continuous removal of noncellulosic components attested by the mass yield decrease after each pretreatment. Besides the overall increase of length and decrease of diameter through pretreatments, box plot parameters (interquartile ranges, whisker lengths, and occurrence of outliers) provided information on withinsample variations (Figure 3).

The alkaline pretreatment demonstrated the lowest yield, indicating the highest removal of noncellulosic compounds. Sequential bleaching steps (Bc_1 $1 \times 2 \mathrm{~h}$ and $\mathrm{Bc} 2 \mathrm{2} \times 3 \mathrm{~h}$ ) decreased fiber mass by $34 \%$ and $36 \%$, respectively, indicating lower but continuous removal of noncellulosic compounds compared to alkaline pretreatment. Hemicelluloses are easily hydrolyzed and removed through alkalization. On the other hand, effective removal of lignin depends on the additional activity of $\mathrm{H}_{2} \mathrm{O}_{2}$ during bleaching, which degrades its tridimensional structure into soluble fragments (Barneto et al., 2011). The removal of surface lignin from the fiber wall changes the fiber microstructure (Brígida et al., 2010). Nanofibrillation requires previous fiber individualization by removing non-cellulosic components. Nonetheless, preserving hemicelluloses up to $13 \%$ benefits water retention and leads to nanofibrils with smaller diameters (Dias et al., 2019).

The alkali pretreatment (Ak) exhibited a higher interquartile range of length than the raw condition, but further bleaching steps (Bc_1 2 2h and Bc_2 3 3h) decreased the variation of most fibers around the mean values. However, longer whiskers at the top of the box plots showed that few pretreated fibers presented much longer lengths than each group's mean value. The alkalization increased fiber length from 1,288 $\pm 516 \mu \mathrm{m}$ (raw) to 1,453 $\pm 544 \mu \mathrm{m}$. The two sequential bleaching steps (Bc_1x2h and $\left.\mathrm{Bc} \_2 \times 3 \mathrm{~h}\right)$ resulted in additional but slight increases of mean fiber lengths to $1,456 \pm 46 \mu \mathrm{m}$ and 1,460 $\pm 487 \mu \mathrm{m}$, respectively.

Alkaline and bleaching pretreatments degrade and remove non-cellulosic components (Beltrami et al., 2014; Zimmermann et al., 2014), which results in better individualization of fibers, thus increasing their lengths (Dong et al., 2020). In the natural condition, açai fibers occur in bundles and have a curly morphology, with fibers convoluted with one another, which can influence length measurements. Exact fiber dimensions vary among different plants, but their overall shape is elongated. In the cellulose and paper industry, long-fibers are obtained from annual plants and gymnosperm woods, while short fibers are exclusively sourced from angiosperm woods. For example, eucalyptus plants have an average fiber length of $820 \mu \mathrm{m}$ (Tonoli et al., 2013), while the mean lengths of Scots pine and Lodgepole pine are 2,150 $\mu \mathrm{m}$ and 2,230 $\mu \mathrm{m}$, respectively (Sable et al., 2012). Therefore, açai fiber's length is closer to short fiber lengths.

Regarding fiber diameter, after pretreatments, the inter-quartile range slightly raised, indicating increased within-sample variations. However, the second bleaching group presents a reduced interquartile range, suggesting better diameter homogenization. Long whiskers observed for raw fibers were markedly shortened after all pretreatments. The vertical position of the diameter box plot dropped down from the raw to the last bleaching step, indicating an overall decrease of diameter. The alkalization (Ak) decreased fiber diameter from $32.7 \pm 9.3$ (raw) to 25 $\pm 7 \mu \mathrm{m}$, kept after the first bleaching (Bc_1 $1 \times 2 \mathrm{~h}$ ). The second bleaching step (Bc_2x3h) resulted in a similar fiber mean diameter of $24 \pm 7 \mu \mathrm{m}$.

Raw fiber diameter is larger than all pretreated ones because of the aggregation of individual fibers by non-cellulosic components, mainly lignin, resulting in fiber bundles (Agopyan, 2005). Interestingly, palm fibers frequently contain silica bodies embedded on craters spread over their surfaces (Omar et al., 2014; Yunos et al., 2012) that facilitate interactions between the inner and outer parts of the fiber (Law et al., 2007). A previous study utilizing the same açai mesocarp fibers confirmed these siliceous surface structures (Oliveira et al., 2019). Therefore, future studies 

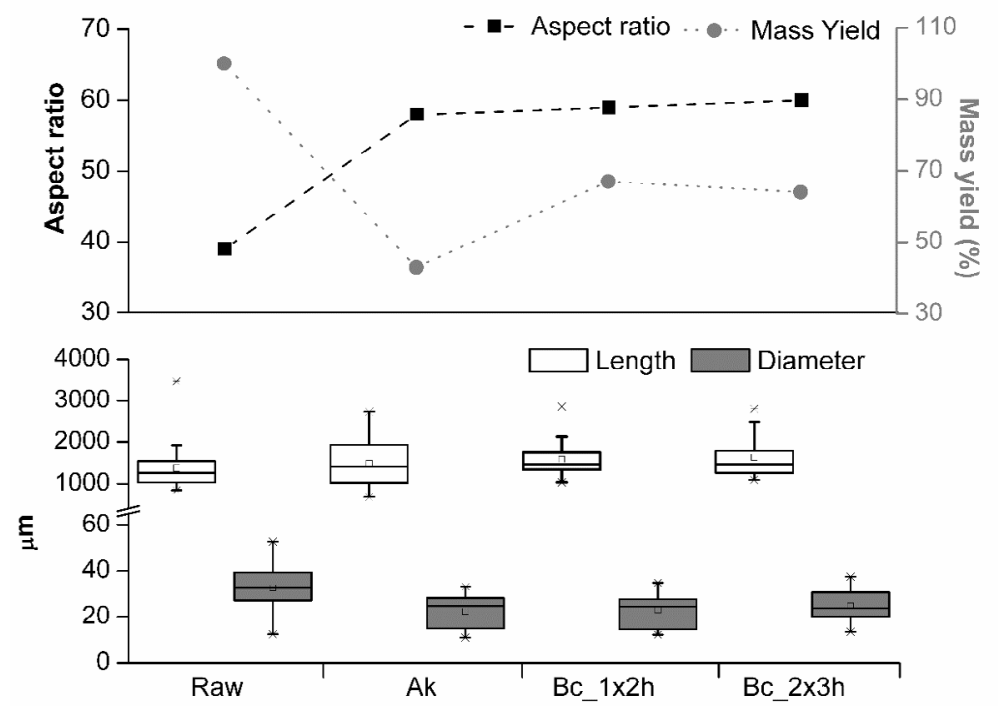

Fig. 3 Mass yield of pretreatments followed by morphological changes of the açai fibers. Ak - alkali pretreated fibers; $\mathrm{Bc}_{-} 1 \times 2 \mathrm{~h}$ - fibers after one bleaching step lasting 2 h; and Bc_2x3h fibers after two bleaching steps, the first lasting $2 \mathrm{~h}$, and the second lasting $3 \mathrm{~h}$. aiming to investigate these siliceous bonding interactions would greatly benefit the current understanding of factors that influence açai fibers' diameter. The decrease of fiber diameter through alkaline and bleaching pretreatments indicates fiber individualization from bundles and favors the nanofibrillation in the grinder. Therefore, a more significant number of nanofibrils will bridge the network of the derived film, increasing hydrogen bindings (Nair et al., 2014).

The aspect ratio can summarize the effect of alkaline and bleaching pretreatments on the combined fiber length and diameter. The alkaline pretreatment improved fiber quality by increasing the aspect ratio to 58 . This value was only slightly lower than 59 and 60 achieved after the first and second bleaching steps (Bc_1 $1 \times 2 h$ and $B c_{-} 2 \times 3 h$ ), respectively. A decreased fiber diameter combined with increased fiber length increases aspect ratio, which confers excellent mechanical properties to micro and nanofibrils within papers and thin films (Berto and Arantes, 2019).

Optical and SEM micrographs confirmed fiber morphology modifications (Figure 4). The tendency of curly raw açai fibers to form bundles with relatively short lengths and large diameters was confirmed (Figures 4b and $4 \mathrm{c}$ ). Some bundles can be handily disaggregated, but efficient fiber individualization requires chemical pretreatments. The alkaline pretreatment (Ak) resulted in individualized fibers with increased length relative to the raw ones (Figures $4 \mathrm{~d}$ and $4 \mathrm{e}$ ). The first bleaching ( $\mathrm{Bc}$ $\mathrm{x} 2 \mathrm{~h}$ ) resulted in largely individualized fibers with a small subset of poorly disintegrated bundles (Figure $4 \mathrm{f}$ and $4 \mathrm{~g}$ ), whereas the second sequential bleaching ( $\mathrm{Bc} \_2 \times 3 \mathrm{~h}$ ) resulted in only individualized fibers (Figure $4 \mathrm{~h}$ and $4 \mathrm{i}$ ). As safranin used in slide preparation colors lignified fiber walls intensely, the lighter tons of the bleached fibers confirm the partial removal of lignin. The SEM micrographs confirm a drastic change in fiber surface microstructure from the raw (Figure $4 \mathrm{a}$ ) to the last bleached condition (Bc_2x3h, Figure $4 \mathrm{j}$ ). The presence of amorphous components and obstructed surfaces are features of raw fibers. Meanwhile, after bleaching, the surface became free from amorphous depositions and "rope-like," indicating the availability of wall microfibrils for nanofibrillation. The surface pores were previously filed with siliceous structures (Oliveira et al., 2019).

The pretreatments promoted the required modifications for nanofibrillation, such as individualization of fibers, removing most non-cellulosic components, and maintaining fiber integrity (Pedrazzi et al., 2013). However, the ideal modification should keep cellulose crystallinity and degree of polymerization (Berto and Arantes, 2019). The X-ray deconvoluted diffractograms of the raw and pretreated açai fibers showed peaks assigned to the (1-10), (110), (200), and (004) planes of cellulose I polymorph. The deconvoluted peak at the $2 \theta$ angle of 42.2 of the raw sample indicated that (004) reflections did not present a dominant contribution. From raw to pretreated states, the amorphous band continuously turned into individualized and high-intensity peaks (Figure 5). The greater peak intensities are consistent with increases in crystallite size and crystalline index. The alkaline pretreatment did not modify the number of cellulose chains per crystallite when compared to raw fibers. However, after bleaching steps (Bc_1 $1 \times 2 h$ and $\left.B c_{-} 2 \times 3 h\right)$, the number of chains increased from 64 to 81, as depicted in Table 1.

The $x$-ray diffractograms attested that alkaline and bleaching pretreatments of the açai fibers did not promote the conversion of cellulose I to cellulose II (French, 2014). Conversion to cellulose II by chemical reactions may hinder nanofibrillation because of the facilitated aggregation caused by the interdigitation of microfibrils in the cell wall (Wang et al., 2014). Importantly, there is a relationship between Segal crystalline index and the relative crystallite

Tab. 1 Crystalline index, crystallite size, and cellulose chains per crystallite of the raw and pretreated açai fibers.

\begin{tabular}{cccc}
\hline Fiber condition & $\begin{array}{c}\text { Crystallite size } \\
(\AA)\end{array}$ & $\begin{array}{c}\text { Cellulose chains } \\
\text { per crystallite }\end{array}$ & $\begin{array}{c}\text { Crystalline } \\
\text { index (\%) }\end{array}$ \\
\hline Raw & 53.2 & 64 & 17.7 \\
Ak & 59.1 & 64 & 44.8 \\
Bc_1x2h & 61.8 & 81 & 61.1 \\
Bc_2x3h & 64.4 & 81 & 68.2 \\
\hline
\end{tabular}

Ak: alkaline pretreatment; $\mathrm{Bc}_{-} 1 \times 2 \mathrm{~h}$ : one bleaching lasting $2 \mathrm{~h}$; and $\mathrm{Bc}_{2} 2 \times 3 \mathrm{~h}$ : two bleaching steps, the first lasting $2 \mathrm{~h}$, and the second lasting $3 \mathrm{~h}$. 

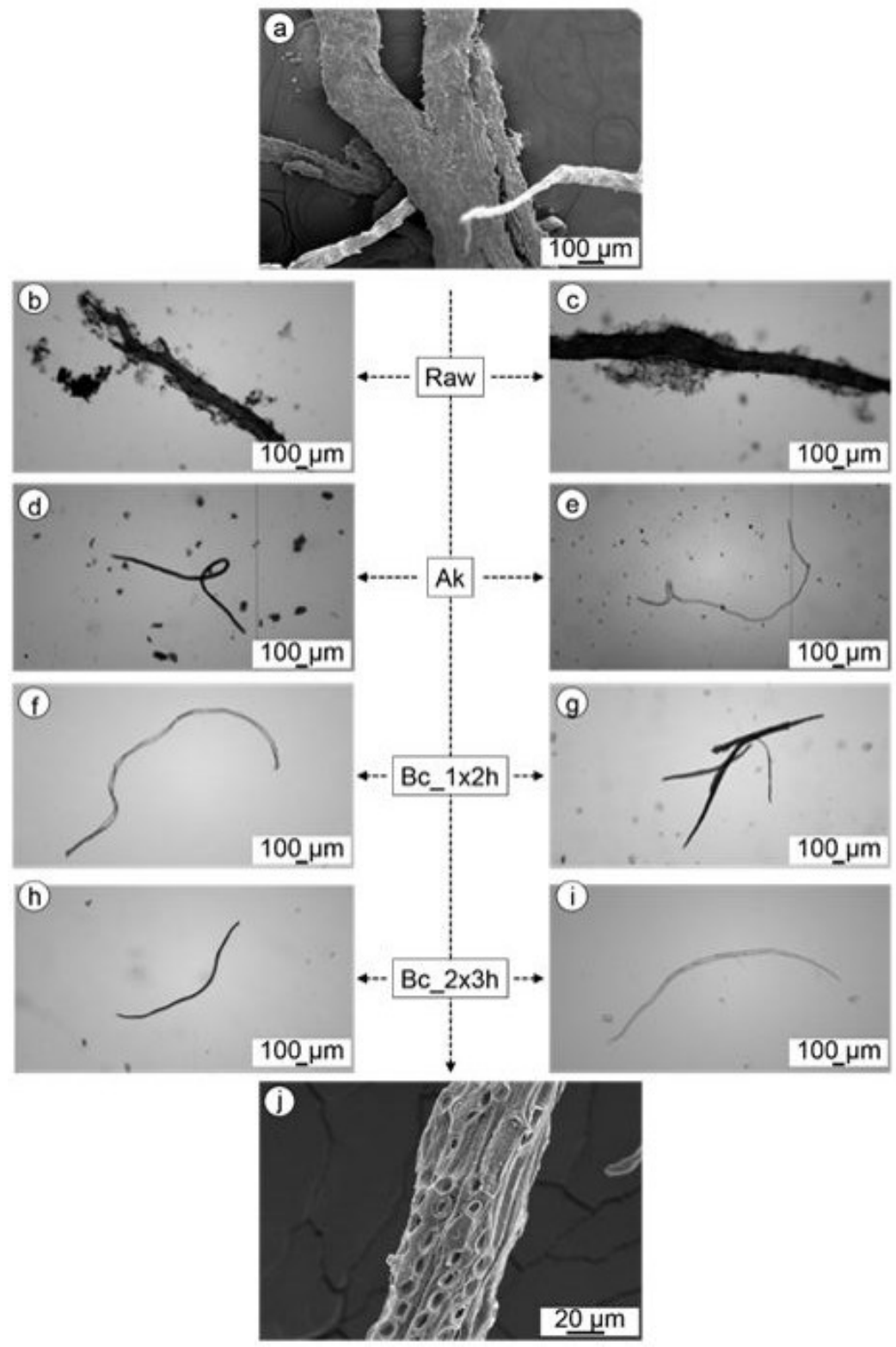

size for a given polymorph (French and Cintrón, 2013). One hypothesis explaining the increase in crystallite size is the co-crystallization phenomenon (Carrillo-Varella et al., 2018). Another possibility is a supramolecular reorganization of cellulose after removing non-cellulosic components (Corrêa et al., 2010). This reorganization is likely to occur, as the intermolecular $\mathrm{H}$-bondings in cellulose-cellulose interactions are stronger than those in cellulose/lignin and cellulose/hemicelluloses ones (Carrillo-Varella et al., 2018). For açai mesocarp fibers, the removal of surface silica bodies by chemical pretreatments is essential to increase the crystalline index (Oliveira et al., 2019). The high amounts of inorganic-amorphous components distributed in the cell wall of açai fibers explain its low crystalline index in the raw condition (17.7\%).

From the alkaline pretreatment (Ak_1x2h) to the first bleaching (Bc_1 $\times 2 \mathrm{~h}$ ), the further removal of hemicelluloses and lignin, which favors condensed structures, likely explains the increase in the number of cellulose chains
Fig. 4 Optical (b to i) and SEM (a and j) micrographs showing the morphology of açai fibers: (a), (b), and (c) raw; (d) and (e) alkali pretreated fibers $(\mathrm{Ak}) ;(\mathrm{f})$ and $(\mathrm{g})$ fibers after one bleaching step lasting $2 \mathrm{~h}$ (BC_1 $1 \times 2 \mathrm{~h}$ ).
(Miranda et al., 2015). This change is probably related to further supramolecular reorganization of the cellulose structure. The increases in crystallite size and crystalline index support such a possibility. The second bleaching $\left(B c \_2 \times 3 h\right)$ increased the crystallite size and crystalline index, benefiting the fibers' mechanical strength and the filmforming performance (Chen et al., 2011).

Although nanofibrils offer much more attractive properties than fibers in the context of biomaterials, the high energy consumption of the mechanical fibrillation process is still a significant barrier for its use on an industrial scale (Desmaisons et al., 2017). Therefore, pretreatments to digest fibers (Dias et al., 2019) and remove a fraction of the noncellulosic components are necessary. It was verified that a $5 \% \mathrm{NaOH}$ pretreatment lasting $2 \mathrm{~h}$ favored the fibrillation process, resulting in $38 \%$ and $62 \%$ of energy savings during the respective processing of eucalyptus and pine pulps up to the point of a gel consistency (Dias et al., 2019). 

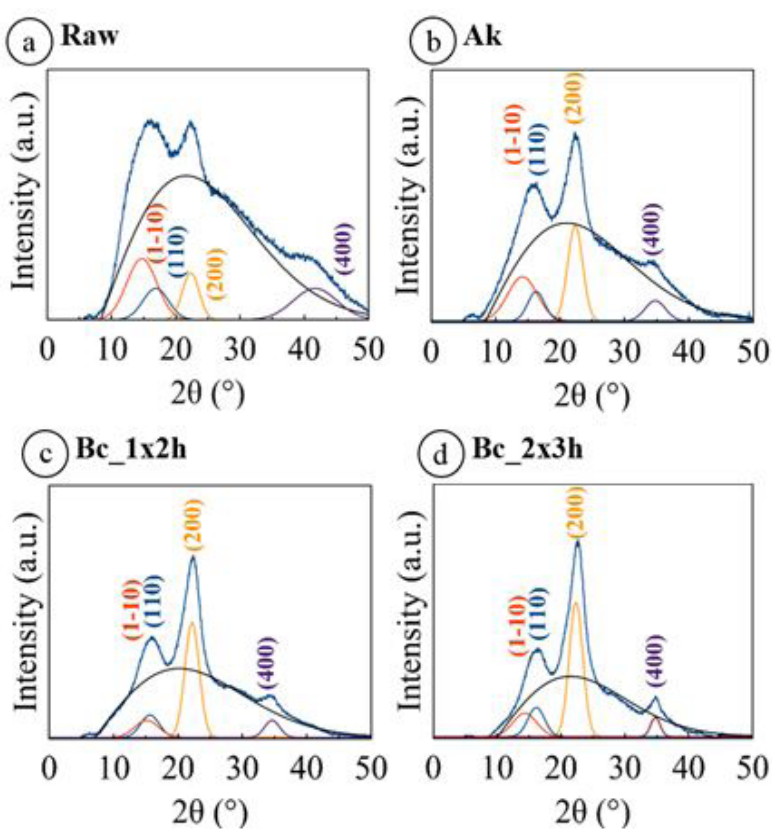

Fig. 5 X-ray diffraction patterns of açai fibers submitted to deconvolution depicting crystalline and amorphous contributions of the samples: (a) raw; (b) alkali pretreated fibers (Ak); (c) fibers after one bleaching step lasting $2 \mathrm{~h}$ (Bc_1x2h); and (d) fibers after two bleaching steps, the first lasting $2 \mathrm{~h}$ and the second lasting $3 \mathrm{~h}$ (Bc_2x3h).

\section{Nanostructured films produced with nanofibrils obtained by 3 or $\mathbf{2 1}$ grinding cycles}

Diffractograms of the films produced with nanofibrils submitted to 3 (FNC_3P) and 21 (FNC_21P) grinding cycles exhibited prominent peaks around $16^{\circ}$ and $22^{\circ}$, characteristics of cellulose I, the same polymorph observed in the starting bleached fibers (Bc_2x3h). The FNC_21P films showed diffraction peaks with lower FWHM (full width at half maximum) than FNC_3P films (Figure 6). The FWHM differences between diffraction peaks of films agreed with the crystallite size and crystalline index. A higher number of cellulose chains per crystallite was observed for films produced with fibers submitted to 21 nanofibrillation cycles (Table 2).

Regarding the starting materials (Bc_2 $2 \times 3)$, films produced with fibers submitted to 3 grinding cycles (FNC_3P) achieved a lower crystalline index when compared to the ones formed by fibers ground 21 times (FNC_21P). However, even the FNC_21P films had a lower crystalline index than the starting fibers (68.2\%). The lower crystalline index observed in films might be associated with the depolymerization of cellulose due to its fragility (Dilamain and Noroozi, 2019). In this case, a further decrease in the crystalline index could be expected from 3 to 21 cycles of nanofibrillation, which was not observed. A possible explanation lies in the effect of nanofibrillation's degree on the delamination of the fiber cell wall layers. The fibers' most external layers, the primary cell wall $(P)$ and the sublayer of the secondary cell wall (S1), contain levels of lignin and hemicelluloses proportionally higher than the cellulose one (Wang et al., 2012). Therefore, increasing nanofibrillation cycles possibly caused the delamination of $P$ and S1, exposing the second sublayer of the secondary wall (S2), which is richer in crystalline cellulose (Jonoobi et al., 2011; Thuault et al., 2015).

Films had increased crystallite size compared to the starting bleached fibers (Bc_2x3h), while the number of cellulose chains increased remarkably (from 81 to 121) for more cycles in the grinder (21 passages). These results are attributed to the drying process of nanofibril suspensions, resulting in a network of hydrogen bonding among nanofibrils that agglomerate and interact within the nanostructured film (Zimmermann et al., 2004). Increases in the crystalline index and crystal size influence the mechanical properties of the thin nanofibril films positively (Iwamoto et al., 2017).

SEM micrographs show the morphology of the nanofibril films. Morphological features of FNC_3P films were more irregular thickness, a rougher surface, and a less compacted structure, with visible voids between layers when compared to FNC_21P films. The film structure directly influences barrier performance and recommended uses (Figure 7).

FNC_3P films presented larger fiber fragments on their surface, indicating poor nanofibrillation. It was evident that three (3) cycles in the grinder were not enough to complete nanofibrillation of açai bleached fibers. On the other hand, FNC_21P films showed more cohesive and uniform structures, resulting from an efficient disintegration of fibers into nanofibrils of high surface area (Scatolino et al., 2017). These nanofibrils favored a denser packaging during drying and, consequently, a more compact structure (Abe and Yano, 2009).

The FNC_3P films showed a slightly lower bulk density, a remarkably lower barrier strength, and a similar mechanical strength when compared to the FNC_21P films (Table 3).
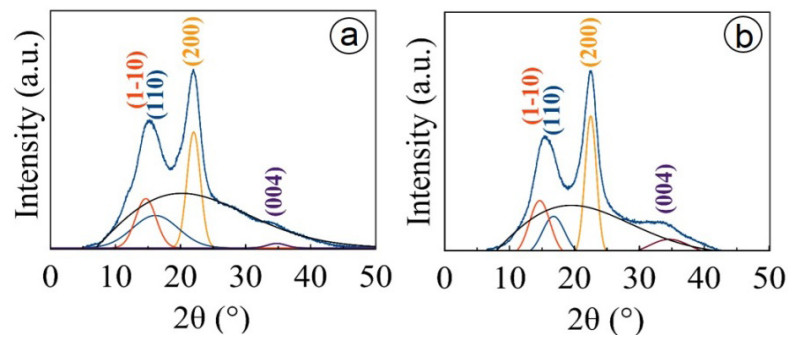

Fig. $6 \mathrm{X}$-ray diffraction patterns of nanofibril films submitted to deconvolution in order to determine crystalline and amorphous contributions of the samples: (a) films produced after 3 cycles (FNC_3P); and (b) films produced after 21 cycles (FNC_21P).

Tab. 2 Crystalline index, crystallite size, and cellulose chains per crystallite for the films produced with nanofibrils obtained after 3 (FNC_3P) and 21 (FNC_21P) grinding cycles.

\begin{tabular}{ccc}
\hline Fiber condition & FNC_3P & FNC_21P \\
\hline Crystalline index $(\%)$ & 55 & 63 \\
Crystallite size $(\AA)$ & 67 & 78 \\
Cellulose chains per crystallite & 81 & 121 \\
\hline
\end{tabular}




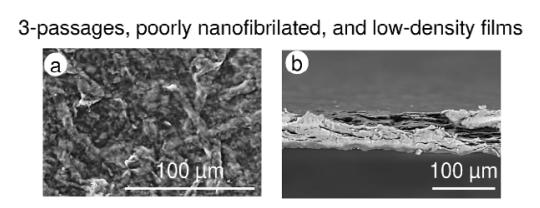

(e) WS

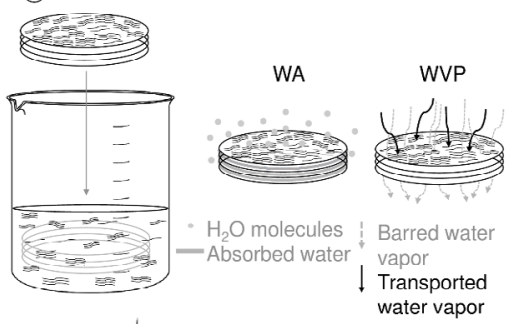

(g)

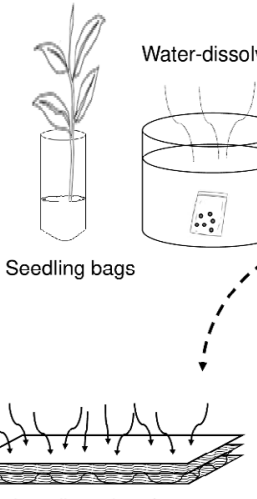

Coated cardboard surface

The difference in bulk density and the basis weight of the açai nanofibrils films was consistent with their morphologies. Increased density and basis weight of the films favors the mechanical and barrier strength of the films (Mirmehdi et al., 2018). After 5 and 20 cycles (comparable to the cycle number applied herein) in the grinder, films produced from pine kraft cellulose nanofibrils exhibited bulk densities of $1.09 \mathrm{~g} \cdot \mathrm{cm}^{-3}$ and $1.13 \mathrm{~g} \cdot \mathrm{cm}^{-3}$, respectively (Viana et al., 2017). The density of starch and carrageenan films varied from 1.2 to $1.4 \mathrm{~g} \cdot \mathrm{cm}^{-3}$ (Lopes et al., 2018). For films comprised of plain starch and a blend of $75 \%$ polyvinyl alcohol (PVA) and 25\% of starch, bulk densities achieved 1.2 $\mathrm{g} \cdot \mathrm{Cm}^{-3}$ and $1.1 \mathrm{~g} \cdot \mathrm{cm}^{-3}$, respectively (Begum et al., 2019).

The more cohesive structure of FNC_21 films also resulted in a lower water solubility than FNC_3P films (Scatolino et al., 2017). Since cellulose is a relatively stable polymer that does not dissolve in water easily (Lan et al., 2011), solubility observed for the FNC_3P samples is probably related to the leaching of poorly fibrillated fibers, not well attached to the film structure. Water solubility is highly relevant when determining suitable applications for films. For instance, in food packaging, films with lower solubility reduce food texture problems (Almeida et al., 2013). Furthermore, when the food is liquid, low solubility films are required (Ayranci and Tunc, 2003). For other applications, particularly when the packaging is coconsumed with the product (Fakhouri et al., 2007), a higher solubility is desirable. These include films used to package dehydrated food, which must disintegrate on contact with hot water (Siracusa et al., 2008). Edible packaging of ingredients or food additives (individual portions of soups, teas, sugars, and seasonings) are examples of when high solubility is needed for instantaneous dissolution (Ayranci and Tunc, 2003). Films applied in the encapsulation of foods or additives (Bertuzzi et al., 2007), as well as in agricultural seed covers (Bertan et al., 2005), also demand high solubility. Overall, nanofibril films have a lower water solubility than those derived from carrageenan or starch, which solubilize approximately 99\% (Lopes et al., 2018), but higher than others like PLA, which solubilize only 2\% (Sanyang et al., 2016). Açai FNC_21P films showed water solubility within the range of $3 \%$ to $7 \%$. A similar range was reported for nanofibril films produced from bleached wood fibers with 10 and 20 cycles in a grinder, respectively (Scatolino et al., 2017). Water solubility between $19 \%$ and $22 \%$ was reported

Tab. 3 Physical, barrier, and tensile properties of the nanofibril films produced after 3 (FNC_3P) and 21 (FNC_21P) cycles of nanofibrillation.

\begin{tabular}{ccc}
\hline Properties & FNC_3P & FNC_21P \\
\hline Thickness $(\mu \mathrm{m})$ & $38.41 \pm 12.03$ & $0.44 \pm 0.10$ \\
Basis weight $\left(\mathrm{g} \cdot \mathrm{m}^{-2}\right)$ & $42.22 \pm 4.40$ & $53.82 \pm 1.80$ \\
Bulk density $\left(\mathrm{g} \cdot \mathrm{cm}^{-3}\right)$ & $1.21 \pm 0.02$ & $1.26 \pm 0.18$ \\
Water solubility $(\%)$ & $30.85 \pm 4.58$ & $6.63 \pm 0.60$ \\
Water vapor absorption (\%) & $75.42 \pm 5.59$ & $39.57 \pm 1.56$ \\
Water vapor permeability rate $\left(\mathrm{g} \cdot \mathrm{h}^{-1} \cdot \mathrm{m}^{2}\right)$ & $74.49 \pm 0.53$ & $44.38 \pm 0.62$ \\
Water vapor permeability & $62.51 \pm 2.12$ & $36.75 \pm 0.80$ \\
(g.mm KPa ${ }^{-1}$ day $\left.{ }^{-1} \mathrm{~m}^{2}\right)$ & $35.80 \pm 11.32$ & $38.95 \pm 4.54$ \\
Maximum tension (MPa) & $5.92 \pm 2.15$ & $6.43 \pm 2.11$ \\
Young modulus (GPa) & $0.47 \pm 0.12$ & $0.46 \pm 0.08$ \\
\hline Strain (\%) & &
\end{tabular}


for fish myofibrillar protein films (Kaewprachu et al., 2016), whereas corvine protein films demonstrated solubility between $18.3 \%$ and $27.6 \%$ (Cortez-Vega et al., 2013). These types of films are recommended for applications requiring easy solubilization. Therefore, the value found for FNC_3P films (30.85\%) indicates high solubility potential.

Films with higher density often demonstrate low water vapor absorption because their compact structure provides fewer voids for water vapor uptake (Scatolino et al., 2017), as observed for FNC_21P films. Scatolino et al. (2017) reported water vapor absorption rates of 5\% and $15 \%$ for nanofibril films produced with 10 and 20 cycles in the grinder. The water vapor absorption of FNC_3 films was within the range observed for starch films of 30\% to $70 \%$ (Lopes et al., 2018), and higher than that reported for plasticized starch, 50\% (Cao et al., 2008). Water vapor is one of the main factors that alter the perceived quality and storage stability of some foods. In addition, its absorption interferes with the films' mechanical properties (Gontard et al., 1994).

The FNC 3P films were more permeable to water vapor $\left(\right.$ WVPR $=74.49 \mathrm{~g} \cdot \mathrm{h}^{-1} \cdot \mathrm{m}^{2}$ and $W V P=62.51 \mathrm{~g} \mathrm{~mm}$ $\mathrm{KPa}^{-1} \cdot \mathrm{day}^{-1} \cdot \mathrm{m}^{2}$ ) than the FNC_21P films (WVPR $=44.38 \mathrm{~g} \cdot \mathrm{h}^{-1}$. $\mathrm{m}^{2}$ and $W V P=36.75 \mathrm{~g} \mathrm{~mm} \mathrm{KPa}^{-1} \cdot \mathrm{day}^{-1} \cdot \mathrm{m}^{2}$ ). Their higher permeability is closely related to the lower nanofibrillation degree and, consequently, reduced interactions among hydrogen bonding in the net, which increased the voids and favored moisture transference across the films. Cellulose is a hydrophilic polymer with high water absorption capacity; however, when disintegrated to nanoscale particles followed by drying, it forms a very compact net of nanofibrils, which creates a tortoise path for water molecules increasing diffusion resistance (Mirmehdi et al., 2018).

Reduced permeability to gases and liquids improves the films' desirability in most packaging applications (Wang et al., 2005). For instance, the use of conventional writing and printing papers and paperboards is restricted for packaging, given their porosity and permeability that confer poor barrier properties (Hult et al., 2010). As the major water vapor transport occurs by diffusion through inter-fiber void space (Spence et al., 2011), the nanofibrils can be applied as coatings on paper surfaces by spraying, improving barrier properties (Mirmehdi et al., 2018). Nonetheless, very permeable films may be suitable for fresh vegetables' packaging, while films of low permeability are often preferred for dehydrated products (Sobral, 2000).

Nanofibril films produced from bleached wood fibers of four species, including eucalyptus, with 10 and 20 cycles in the grinder showed water vapor permeability within the range of $60 \mathrm{~g} \mathrm{~mm} \mathrm{KPa}^{-1} \cdot \mathrm{day}^{-1} \cdot \mathrm{m}^{2}$ to $120 \mathrm{~g} \mathrm{~mm} \mathrm{KPa}^{-1} \cdot \mathrm{day}^{-1} \cdot \mathrm{m}^{2}$ (Scatolino et al., 2017). Thus, açai nanofibrils provided films with better barrier properties. Overall, cellulose nanofibril films show higher water vapor permeability than those derived from other natural polymers such as carrageenan, $\sim 22 \mathrm{~g} \mathrm{~mm} \mathrm{KPa}{ }^{-1} \cdot$ day $^{-1} \cdot \mathrm{m}^{2}$ starch, $15 \mathrm{~g} \mathrm{~mm} \mathrm{KPa}^{-1} \cdot$ day $^{-1} \cdot \mathrm{m}^{2}$ (Lopes et al., 2018), myofibrillar protein, from $6.91 \mathrm{~g} \mathrm{~mm}^{-1}$ $\mathrm{KPa}^{-1} \cdot$ day $^{-1} \cdot \mathrm{m}^{2}$ to $24.27 \mathrm{~g} \mathrm{~mm} \mathrm{KPa}{ }^{-1} \cdot$ day $^{-1} \cdot \mathrm{m}^{2}$ (Kaewprachu et al., 2016), and corvine protein, $5.5 \mathrm{~g} \mathrm{~mm} \mathrm{KPa}^{-1}$.day ${ }^{-1}$. $\mathrm{m}^{2}$ (Cortez-Vega et al., 2013). Meanwhile, all permeability values reported in the literature for industrial polymeric films are much lower than those attained for açai nanofibril ones. For example, $2.15 \mathrm{~g} \mathrm{~mm} \mathrm{KPa}{ }^{-1}$. day ${ }^{-1} \cdot \mathrm{m}^{2}$ for polyvinyl chloride (PVC) (Kaewprachu et al., 2016), $0.02 \mathrm{~g} \mathrm{~mm} \mathrm{KPa}^{-1}$. day $^{-1} \cdot \mathrm{m}^{2}$ for linear low-density polyethylene (LLDPE) (Hong and Rhim, 2012), and $0.69 \mathrm{~g} \mathrm{~mm} \mathrm{KPa}{ }^{-1} \cdot \mathrm{day}^{-1} \cdot \mathrm{m}^{2}$ for PLAderived films (Sanyang et al., 2016).

However, even when the film has desirable water permeability properties, the compatibility between the film and the food must be taken into account (Rioux et al., 2002). Biodegradable films composed of $90 \%$ starch and 10\% PLA are being used commercially in Europe as a fat barrier in butter and margarine packaging. Furthermore, corn-starch and wheat-based garbage bags are available in the markets of Italy, Finland, and Denmark (Haugaard et al., 2001).

Films presented similar mechanical strength, with slightly higher maximum tension and Young modulus for FNC_21P, considering the standard deviation. Complete nanofibrillation leads to films with a uniform and dense structure, which imparts rigidity and mechanical strength (Lavoine et al., 2012; Potulski et al., 2016). The commercial pulp of Pinus radiata resulted in nanofibril films (Iwamoto et al., 2007) with a higher tensile strength ( $\sigma=60-95 \mathrm{MPa})$, a similar Young modulus ( $E=7-8 \mathrm{GPa})$, and a higher strain ( $\varepsilon=0.23-0.25 \%$ ) compared to the films derived from açai fibers. Other natural polymers resulted in films with the following mechanical properties: (i) myofibrillar protein $\sigma=3.00-4.38 \mathrm{MPa}$, and $\varepsilon=33-50 \%$ (Kaewprachu et al., 2016); (ii) plasticized starch $-\sigma=3.9 \mathrm{MPa}, \mathrm{E}=0.03 \mathrm{MPa}$, and $\varepsilon=68.2 \%$ (Cao et al., 2008); and (iii) corvine protein - $\sigma=7.2-10.70 \mathrm{MPa}, \mathrm{E}=0.012-0.017 \mathrm{GPa}$, and $\varepsilon=39.60$ $45.80 \%$ (Cortez-Vega et al., 2013). Films produced with these materials seem to exhibit lower tensile strength, lower Young modulus, and higher strain compared to nanofibril cellulose films derived from açai fibers. PVC films showed $\sigma=46.92 \mathrm{MPa}$ and $\varepsilon=268.31 \%$ (Kaewprachu et al., 2016). LLDPE films exhibited a tensile strength of 24.5 MPa and $\varepsilon=1487 \%$ (Hong and Rhim, 2012). Commercial PLA films demonstrated $\sigma=22.76 \mathrm{MPa}, \mathrm{E}=0.96 \mathrm{GPa}$, and $\varepsilon=7.88 \%$ (Sanyang et al., 2016). The tensile strength of açai nanofibril films is comparable with these values. However, the lower strain of cellulose nanofibril films, in general, is attributed to the improved crystalline structure attained after the removal of non-cellulosic components through chemical pretreatments (Beckermann and Pickering, 2008).

The alkalinized-bleached açaí fibers were converted into promising nanofibrils and derived films with versatile packaging applications. Nevertheless, the results found herein are limited to the açaí mesocarp fibers of the same source and processing history, besides the chemical pretreatments and the exact grinder equipment adjusted according to the details described in the material and methods section of this paper.

\section{CONCLUSIONS}

Açai wastes are widely available throughout the Amazonian region and demonstrated to be a promising source of easily extractable fiber bundles. The fibers are compatible with traditional chemical pretreatment strategies, maintaining cellulose's morphology and 
integrity. Such attributes have attracted interest in using these fibers as a feedstock for subsequent nanofibrillation, with potential applications for barrier films in the packaging industry. The alkaline pretreatment with $5 \% \mathrm{NaOH}$ at $80^{\circ} \mathrm{C}$, followed by two sequential $\mathrm{NaOH} / \mathrm{H}_{2} \mathrm{O}_{2}$, bleaching steps, efficiently removed non-cellulosic components. The bleached fibers exhibited longer lengths, reduced diameters, and higher crystallinity index than the raw fibers while preserved morphology and cellulose I structure. In the adjusted conditions and the grinder equipment tested herein, açaí mesocarp nanofibrils with potential and versatile film applications according to the number of passages were successfully produced. The increase of nanofibrillation cycles from 3 (minimum to the gel point) to 21 (maximum suspension thickness) resulted in nanofibril films with higher crystallinity properties, a uniform thickness, a compacted morphology, and a smoother surface. The two produced films showed similar mechanical strength but significantly distinct physical properties, offering a renewable film biomaterial suitable for different applications such as for barrier in packaging materials. Films produced with fibers submitted to 3 grinding cycles can be recommended for packaging applications that demand high levels of water uptake, solubility, and water vapor transference. Oppositely, fibers subjected to 21 cycles in grinder provide films suitable for water-resistant packaging, ideal for secondary coatings of papers and paperboards. The present work contributes with information for evolution of the new generation of cellulose packaging materials with high barrier properties.

\section{ACKNOWLEDGMENTS}

The authors are grateful to the National Council for Scientific and Technological Development (CNPq) for the support through scholarships and financial support (research project's process number 431553/2016-5, public call CNPq Universal 2016), and to the Coordination for the Improvement of Higher Level Personnel (CAPES) for the scholarships.

\section{AUTHORSHIP CONTRIBUTION}

Project Idea: DGB, LB

Funding (F): MGS, GHDT, CFON, LB

Database (D): DGB, JLLA, TMS, MCD, LGG

Processing (P): DGB, JLLA, MGS, PICC, LGG

Analysis (A): DGB, MGS, TMS, CFON, JLLA, PICC, LGG, LB

Writing (W): DGB, TMS, GHDT, CFON, PICC, LB

Review (R): TMS, MCD, GHDT, LB

\section{REFERENCES}

$A B E, K_{\text {; }}$ YANO, $H$. Comparison of the characteristics of cellulose microfibril aggregate wood, rice straw and potato tuber. Cellulose, v. 16, p. 1017-1023, 2009.

AGOPYAN, V.; SAVASTANO JR, H.; JOHN, V. M.; CINCOTTO, M. A. Developments on vegetable fibre-cement based materials in São Paulo, Brazil: an overview. Cement and Concrete Composites, v. 27, n. 5, p. 527-536, 2005.

ALILA, S.; BESBES, I.; VILAR, M. R.; MUTJÉ, P.; BOUFI, S. Non-woody plants as raw materials for production of micribrillated cellulose (MFC): a comparative study. Industrial Crops and Products, v. 41, n. 1, p. 250-259, 2013.
ALMEIDA, D. M.; WOICIECHOWSKI, A. L.; WOSIACKI, G.; PRESTES, R. A. PINHEIRO, L. A. Physical, chemical and barrier properties in films made with bacterial cellulose and potato starch blend. Polímeros: Ciência e Tecnologia, v. 23, n. 4 , p. 538-546, 2013.

ASTM - AMERICAN SOCIETY FOR TESTING AND MATERIALS STANDARD. D882-12: standard test method for tensile properties of thin plastic sheeting. West Conshohocken, 2012

ASTM - AMERICAN SOCIETY FOR TESTING AND MATERIALS STANDARD. E104-02: standard practice for maintaining constant relative humidity by means of aqueous solutions. West Conshohocken, 2012.

ASTM - AMERICAN SOCIETY FOR TESTING AND MATERIALS. 2000. E9600: standard test methods for water vapor transmission of materials. West Conshohocken, 2000.

AYRANCI, E.; TUNC, S. A method for the measurement of the oxygen permeability and the development of edible films to reduce the rate of oxidative reactions in fresh foods. Food Chemistry, v. 80, n. 3, p. 423-431, 2003.

BALLESTEROS, J. E. M.; SANTOS, V.; MÁRMOL, G.; FRÍAS, M.; FIORELLI, J. Potential of the hornification treatment on eucalyptus and pine for fibercement applications. Cellulose, v. 24, p. 2275-2286, 2017.

BARNETO, A. G.; VILA, C.; ARIZA, J. Eucalyptus kraft pulping production: thermogravimetry monitoring. Thermochimica Acta, v. 520, n. 1-2, p. 110120, 2011.

BECKERMANN, G. W.; PICKERING, K. L. Engineering and evaluation of hemp fibre reinforced polypropylene composites: fibre treatment and matrix modification. Composites Part A: Applied Science and Manufacturing, v. 39, n. 6, p. 979-988, 2008.

BEGUM, M. H. A.; HOSSAIN, M. M.; GAFUR, M. A.; KABIR, A. N. M. H.: TANVIR, N. I. MOLLA, M. R. Preparation and characterization of polyvinyl alcoholstarch composites reinforced with pulp. SN Applied Sciences, V. 1, 1091, 2019.

BELTRAMI, L. V. R.; SCIENZA, L. C.; ZATTERA, A. J. Effect of the alkaline treatments of curauá fiber on the properties of biodegradable matrix composites. Polímeros, v. 24, n. 3, p. 388-394, 2014.

BERTAN, L. C.; FAKHOURI, F. M.; SIANI, A. C.; GROSSO, C. R. F. Influence of the addition of lauric acid to films made from gelatin, triacetin and a blend of stearic and palmitic acids. Macromolecular Symposia, v. 229, n. 1, p. 143-149, 2005.

BERTO, G. L.; ARANTES, V. Kinetic changes in cellulose properties during defibrillation into microfibrillated cellulose and cellulose nanofibrils by ultrarefining. International Journal of Biological Macromolecules, v. 127, n. 15, p. 637-648, 2019

BERTUZZI, M. A.; VIDAURRE, E. F.; ARMADA, M.; GOTTIFREDI, J. C. Water vapor permeability of edible starch based films. Journal of Food Engineering, v. 80, n. 3, p. 972-978, 2007.

BONGARDE, U. S. SHINDE, V. D. A review on natural fiber reinforcement polymer composites. International Journal of Engineering Science and Innovative Technology, v. 3, n. 2, p. 431-436, 2014.

BOURTOOM, T.; CHINNAN, M. S. Preparation and properties of rice starch/ chitosan blend biodegradable film. LWT-Food Science and Technology, v. 41, n. 9, p. 1633-1641, 2008.

BRAZILIAN INSTITUTE OF GEOGRAPHY AND STATISTICS. Produção da Extração Vegetal e da Agricultura. IBGE, Rio de Janeiro. Available at: htttps:// sidra.ibge.gov.br/tabela/289. Accessed in: February 15th 2020.

BRÍGIDA, A. I. S.; CALADO, V. M. A.; GONÇALVES, L. R. B.; COELHO, M. A. Z. Effect of chemical treatments on properties of green coconut fiber. Carbohydrate Polymers, v. 79, n. 4, p. 832-838, 2010.

BUFALINO, L.: SENA NETO, A. R: TONOLI, G. H. D: FONSECA, A. S: COSTA, T G. LABORY C: MARCONCINI, I. M: COLODETTE, J. L: MENDES, L, M How the chemical nature of Brazilian hardwoods affects nanofibrillation of cellulose fibers and film optical quality. Cellulose, v. 22, n.6, p. 3657-3672, 2015

BUFALINO, L.; CAIXETA, L. A.; PROTÁSIO, T. PAULA; SCATOLINO, M. V.; MESQUITA, R. G. A.; MENDES, L. M.; TONOLI, G. H. D.; MARCONCINI, J. M. Options for chemical modification of wastes from a Brazilian hardwood species and potential applications. Key Engineering Materials, v. 634, p. 321-328, 2014.

BUFALINO, L: GUIMARÃES, A. A: SILVA, B, M. S: SOUZA, R. L. F: MELO, I. C. N. A; OLIVEIRA, D. N. P. S.; TRUGILHO, P. F. Local variability of yield and physical properties of açaí waste and improvement of its energetic attributes by separation of lignocellulosic fibers and seeds. Journal of Renewable and Sustainable Energy, v. 10, n. 5, p. 053102, 2018.

CAO, X: CHEN, Y: CHANG, P. R: STUMBORG, M: HUNEAULT, M. A Green composites reinforced with hemp nanocrystals in plasticized starch. Journal of Applied Polymer Science, v. 109, n. 6, p. 3804-3810, 2008.

CARRILLO-VARELA, I.; PEREIRA, M.; MENDONÇA, R. T. Determination of polymorphic changes in cellulose from Eucalyptus spp. fibres after alkalization. Cellulose, v. 25, p. 6831-6845, 2018.

CASTRO, C. D. P. C.; DIAS, C. G. B. T.; FARIA, J. D. A. F. Production and evaluation of recycled polymers from açaí fibers. Materials Research, v. 13 n. 2, p. 159-163, 2010. 
CHEN, W.; YU, H.; LIU, Y.; HAI, Y.; ZHANG, M.; CHEN, P. Isolation and characterization of cellulose nanofibers from four plant cellulose fibers using a chemical-ultrasonic process. Cellulose, v. 18, n. 2, p. 433-442, 2011.

CORRÊA, A. C.; TEIXEIRA, E. M.; PESSAN, L. A.; MATTOSO, L. H. C. Cellulose nanofibers from curaua fibers. Cellulose, v. 17, n. 6, p. 1183-1192, 2010.

CORTEZ-VEGA，W. R.; BAGATINI, D. C.; SOUZA， J. T. A. D.; PRENTICE, C. Nanocomposite biofilms obtained from Whitemouth croaker (Micropogonias furnier) protein isolate and Monmorilonite: Evaluation of the physical, mechanical and barrier properties. Brazilian Journal of Food the physical, mechanical and barrier
Technology, v. 16, n. 2, p. 90-98, 2013.

DESMAISONS, J.; BOUTONNET, E.; RUEFF, M.; DUFRESNE, A.; BRAS, J. A new quality index for benchmarking of different cellulose nanofibril. Carbohydrate Polymers, v. 174, p. 318-329, 2017.

DIAS, M. C.; MENDONÇA, M. C.; DAMÁSIO, R. A. P.; ZIDANES, U. L.; MORI, F. A.; FERREIRA, S. R.; TONOLI, G. H. D. Influence of hemicellulose content of Eucalyptus and Pinus fibers on the griding process for obtain cellulose micro/nanofibrils. Holzforschung, v. 73, n. 11, p. 1035-1046, 2019.

DILAMIAN, M.; NOROOZI, B. A. A combined homogenization-high intensity ultrasonication process for individualization of cellulose micro-nano fibers from rice straw. Cellulose, v. 26, p. 5831-5849, 2019.

DONG, Y.; WANG, B.; J, H.; ZHU, W.; LONG, Z.; DONG, C. Effect of papermaking conditions on the ink absorption and overprint accuracy of paper. BioResource, v. 15, n. 1, p. 1397-1406, 2020.

FAKHOURI, F. M.; MARTELLIA, S. M.; CAONC, T.; VELASCOD, J. I.; MEI, L. H. I. Films and edible coatings based on native starches and gelatin in the conservation and sensory acceptance of Crimson grapes. Ciência e the conservation and sensory acceptance of Crims
Tecnologia de Alimentos, v. 27, n. 2, p. 369-375, 2007.

FONSECA, A. S.; PANTHAPULAKKAL, S.; KONAR, S. K.; SAIN, M.; BUFALINO L.; RAABE, J.; MIRANDA, I. P. A.; MARTINS, M. A.; TONÓLI, G. H. D. Improving cellulose nanofibrillation of non-wood fiber using alkaline and bleaching pretreatments. Industrial Crops and Products, v. 131, n. 5, p. 203-212, 2019.

FONSECA, C. S.; SILVA, T. F.; SILVA, M. F.; OLIVEIRA, I. R. C.; MENDES, R. F.; HEIN, P. R. G.; MENDES, L. M.; TONOLI, G. H. D. Eucalyptus cellulose micro/nanofibrils in extruded fiber-cement composites. Cerne, v. 22, n. 1, p. 59-68, 2016.

FRAGA, L. A.; TAVARES, M. I. B. Study of different conditions of mercerisation of the fibres of the seed of açai (Euterpe oleracea). Semioses, v. 11, n. 3, p 49-54, 2017.

FRENCH, A. D. Idealized powder diffraction patterns for cellulose polymorphs Cellulose, v. 21, p. 885-896, 2014.

FRENCH, A. D.; CINTRÓN, M. S. Cellulose polymorphy, crystallite size, and the Segal Crystallinity Index. Cellulose, v. 20, p. 583-588, 2013

GONTARD, N.; DUCHEZ, C.; CUQ, J.; GUILBERT, S. Edible composite films of wheat gluten and lipids: water vapour permeability and other physical properties. International Journal of Food Science and Technology, v. 29, n. 1, p. 39-50, 1994

GUIMARÃES JÚNIOR, M.; BOTARO, V. R.; NOVACK, K. M.; TEIXEIRA, F. G. TONOLI, G. H. D. Starch/PVA-based nanocomposites reinforced with bamboo nanofibrils. Industrial Crops and Products, v. 70, p. 72-83, 2015.

GUIMARÃES JUNIOR, M.; BOTARO, V. R.; NOVACK, K. M.; TEIXEIRA, F. G.; TONOLI, G. H. D. High moisture strength of cassava starch/PVA compatible blends for packaging and agricultural sector. Journal of Polymer Research, v. 22, p. $1-18,2015$

HASSAN, M. L.; MATHEW, A. P.; HASSAN, E. A.; EL-WAKIL, N. A.; OKSMAN, K. Nanofibers from bagasse and rice straw: process optimization and properties. Wood Science and Technology, v. 46, p. 193-205, 2012

HAUGAARD, V. K.; UDSEN, A. M.; MORTENSEN, G.; HØEGH, L. P.; MONAHAN K. F. Potential food applications of biobased materials. An EU-concerted action project. Starch, v. 53, n. 5, p. 189-200, 2001

HONG, S.-I.; RHIM, J.-W. Preparation and properties of melt-intercalated linear low density polyethylene/clay nanocomposite films prepared by blow extrusion. LWT-Food Science and Technology, v. 48, n. 1, p. 43-51, 2012.

HULT, E. L.; IOTTI, M.; LENES, M. Efficient Approach to High Barrier Packaging Using Microfibrillar Cellulose and Shellac. Cellulose, v. 17, p. 575-586, 2010.

IWAMOTO, S.; NAKAGAITO, A. N.; YANO, H. Nano-fibrillation of pulp fibers for the processing of transparent nanocomposites. Applied Physics A, V. 89, p. $461-466,2007$.

JONOOBI, M.; HARUN, J.; TAHIR, P. M.; SHAKERI, A.; SAIFULAZRY, S.; MAKINEJAD, M. D. Physicochemical characterization of pulp and nanofibers from kenaf stem. Materials Letters, v. 65, n. 7, p. 1098-1100, 2011

KAEWPRACHU, P., OSAKO, K.; BENJAKUL, S.; RAWDKUEN, S. Effect of protein concentrations on the properties of fish myofibrillar protein based film compared with PVC film. Journal of Food Science and Technology, v. 53, p. 2083-2091, 2016.

KAKROODI, A. R.; CHENG, S.; SAIN, M.; ASIRI, A. Mechanical, thermal and morphological properties of nanocomposites based polyvinyl alcohol and cellulose nanofiber from Aloe vera Rind. Journal of Nanomaterials, v. 2014, p. 1-7, 2014
KHANAM, P. N.; REDDY, M. M.; RAGHU, K.; JOHN, K.; NAIDU, S. V. Tensile, flexural and compressive properties of sisal/silk hybrid composites. Journal of Reinforced Plastic Composites, v. 26, n. 10, p. 1065-1070, 2007

LAN, W.; LIU, C. F.; SUN, R. G. Fractionation of bagasse in cellulose, hemicelluloses and lignin with ionic liquid treatment followed by alkaline extraction. Journal of Agricultural and Food Chemistry, v. 59, n. 16, p. 86918701, 2011.

LANGFORD, J. I.; WILSON, A. J. C. Scherrer after sixty years: a survey and some new results in the determination of crystallite size. Journal of Applied Crystallography, v. 11, n. 2, p.102-113, 1978.

LAVOINE, N.; DESLOGES, I.; DUFRESNE, A.; BRAS, J. Microfibrillated cellulose - Its barrier properties and applications in cellulosic materials: a review. Carbohydrate Polymers, v. 90, n. 2, p. 735-764, 2012.

LAW, K.-N.; DAUD, W. R. W.; GHAZALI, A. Morphological and chemical nature of fiber strands of Oil Palm Empty-Fruit-Bunch (OPEFB). BioResources, v. 2, n. 3, p. 351-362, 2007.

LOPES, T. A.; BUFALINO, L.; JÚNIOR, M. G.; TONOLI, G. H. D.; MENDES, L. $M$. Eucalyptus wood nanofibrils as reinforcement of carrageenan and starch biopolymers for improvement of physical properties. Journal of Tropical Forest Science, v. 30, n. 3, p. 292-303, 2018

MARANHO, A. S. S.; PAIVA, A. V. Seedling emergence of supiarana (Alchornea discolor Poepp.) in substrate composed by different percentages of açaí organic waste. Journal of Brazilian Society of Urban Forest, v. 6, n. 1, p. 85-98, 2011

MARTINS, M. A.; PESSOA, J. D. C.; GONÇALVES, P. S.; SOUZA, F. I.; MATTOSO, L. H. C. Thermal and mechanical properties of the açai fiber/natural rubber composites. Journal of Materials Science, v. 43, p. 6531-6538, 2008.

MESQUITA, R. G. A.; CÉSAR, A. A. S.; MENDES, L. M.; MARCONCINI, J. M.; TONOLI, G. H. D. Polyester composites reinforced with maleic anhydridetreated filaments from mauve. Cerne, v. 24, n. 1, p. 1-8, 2018.

MIRANDA, C. S.; FIUZA, R. P.; CARVALHO, R. F.; JOSE, N. M. Effect of surface treatment on properties of bagasse piassava fiber Attalea funifera Martius. Química Nova, v. 38, n. 2, p. 161-165, 2015.

MIRMEHDI, S.; OLIVEIRA, M. L. C.; HEIN, P. G.; DIAS, M. V.; SARANTÓPOULOS, C. I. G. L.; TONOLI, G. H. D. Spraying cellulose nanofibrils for improvement of tensile and barrier properties of writing \& printing (W\&P) paper. Journal of Wood Chemistry and Technology, v. 38, n. 3, p. 233-245, 2018.

NAEIMI, A.; HONARMAND, M.; JAWHID, O. Iron porphyrin immobilized on cellulose extracted from Sesbania sesban plant: a novel eco-friendly and cost effective catalyst for green oxidation of organic compounds. Cellulose Chemistry and Technology, v. 52, n. 5-6, p. 343-351, 2018.

NAIR, S. S.; ZHU, J. Y.; DENG, Y.; RAGAUSKAS, A. J. Characterization of cellulose nanofibrillation by micro grinding. Journal of Nanoparticle Research, v. 16, p. 1-10, 2014.

NECHYPORCHUK, O.; BELGACEM, M. N.; BRAS, J. Production of cellulose nanofibrils: a review on recent advances. Industrial Crops and Products, $v$. 93, p.2-25, 2016

OLIVEIRA, D. N. P. S.; CLARO, P. I. C.; FREITAS, R. R.; MARTINS, M. A.; SOUZA, T. M.; SILVA, B. M. S.; MENDES, L. M.; BUFALINO, L. Enhancement of the Amazonian acaí waste fibers through variations of alkali pretreatment parameters. Chemistry \& Biodiversity, v. 16, n. 9, p. 1-12, 2019

OMAR, F. N.: MOHAMMED, M. A. P.; BAHARUDDIN, A. S. Effect of silica bodies on the mechanical behaviour of oil palm empty fruit bunch fibers. BioResources, v. 9, n. 4, p. 7041-7058, 2014

PANTHAPULAKKAL, S.; SAIN, M. Isolation of nano fibers from hemp and flax and their thermoplastic composites. Plastic and Polymer Technology, v. 2, n. 1, p. 9-16, 2013

PEDRAZZI, C. COLODETTE, J. L: OLIVEIRA, R C. D.: WILLE, V. K. D Morphologic evaluation of Eucalyptus kraft pulp fibers with different xylans contents. Scientia Forestalis, v. 41, n. 100, p. 515-522, 2013.

POTULSKI, D. C.; VIANA, L. C.; MUNIZ, G. I. B. D.; ANDRADE, A. S.; KLOCK, U. Characterization of fibrillated cellulose nanofilms obtained at different consistencies. Scientia Forestalis, v. 44, n. 110, p. 361-372, 2016.

PROTÁSIO, T. P.; BUFALINO, L.; TONOLI, G. H. D.; GUIMARÃES JÚNIOR, M.; TRUGILHO, P. F.; MENDES, L. M. Brazilian lignocellulosic wastes for bioenergy production: characterization and comparison with fossil fuels. BioResources, v. 8, n. 1, p. 1166-1185, 2013

RIOUX, B.; ISPAS-SZABO, P.; AIT-KADI, A.; MATEESCU, M.-A.; JUHÁSZA, J. Structure properties relationship in crosslinked high amylose starch cast films. Carbohydrate Polymers, v. 50, n. 4, p. 371-378, 2002.

SABLE, I.; GRINFELDS, U.; JANSONS, A.; VIKELE, L.; IRBE, I.; VEROVKINS, A.; TREIMANIS, A. Comparison of the properties of wood and pulp fibers from lodgepole pine (Pinus contorta) and Scots pine (Pinus sylvestris). Bioresources, v. 7, n. 2, p. 1771-1783, 2012.

SAHEB, D. N.; JOG, J. P. Natural fiber polymer composites: a review. Advanced Polymers Technology, v. 18, n. 4, p. 351-363, 1999. 
SANTANA, A. C.; SANTANA, A. L.; SANTANA, A. L.; SANTOS, M. A. S OLIVEIRA, C. M. Multiple discriminant analysis of the retail açaí market in Belém do Pará. Revista Brasileira de Fruticultura, v. 36, n. 3, p. 532-541, 2014

SANTOS, F. S.; RAMOS, K. S.; BRUM, G. G. G.; GAIA, I. A.; PEREIRA, S. S. P. VIEIRA, A. L. Chagas disease and its transmission by açaí: a bibliographic review. Brazilian Journal of Health Review, v. 2, n. 2, p. 2128 - 2144 2019.

SANYANG, M. L.; SAPUAN, S. M.; JAWAID, M.; ISHAK, M. R.; SAHARI, Development and characterization of sugar palm starch and poly(lactic acid) bilayer films. Carbohydrate Polymers. v. 146, n. 1, p. 36-45, 2016.

SCATOLINO, M. V.: SILVA, D. W.; BUFALINO, L.; TONOLI, G. H. D.; MENDES, L. $M$. Influence of cellulose viscosity and residual lignin on water absorption of nanofibril films. Procedia Engineering, v. 200, p. 155-161, 2017

SCATOLINO, M. V.; BUFALINO, L.; MENDES, L. M.; GUIMARÃES JÚNIOR M.; TONOLI, G. H. D. Impact of nanofibrillation degree of eucalyptus and Amazonian hardwood sawdust on physical properties of cellulose nanofibril films. Wood Science and Technology. v. 51, p. 1095-1115, 2017

SEGAL, L: CREELY, J. J: MARTIN JUNIOR, A. E.; CONRAD, C. M. An empirica method for estimating the degree of crystallinity of native cellulose using the X-ray diffractometer. Textile Research Journal, v. 29, n. 10, p. 786-794, 1959.

SHARMA, A. K.; GODIYAL R.; THAPLIYAL, B. P. Kans grass - a promising raw material for papermaking. Cellulose Chemistry and Technology, v. 53, n. 7-8, p. 747-753, 2019

SHULGA, G.; NEIERTE, B.; VEROVKINS, A.; VITOLINA, S.; JAUNSLAVIETIS, J. LIVCHA, S.; BETKERS, T. Aminated wood sanding dust as filler for recycled polypropylene-based composite. Cellulose Chemistry and Technology, v. 53, n. $9-10$, p. $945-953,2019$

SIRACUSA, V.; ROCCULI, P.; ROMANI, S.; ROSA, M. D. Biodegradable polymer for food packaging: a review. Trends Food Science and Technology v 19 , 12 , p. $634-643,2008$

SOBRAL, P. J. A. Thickness effects of myofibrillar protein based edible films on their functional properties. Pesquisa Agropecuária Brasileira, v. 35, n. 6 p. $1251-1259,2000$

SOUZA, L. O.; LESSA, O. A.; DIAS, M. C.; TONOLI, G. H. D.; REZENDE, D. V. B MARTINS, M. A.: NEVES, I. C. O.: RESENDE, J. V.: CARVALHO, E. E. N.: BOAS, E V. B. V.; OLIVEIRA, J. R.; FRANCO, M. Study of morphological properties and rheological parameters of cellulose nanofibrils of cooca shell (Theobram cacao L.). Carbohydrate Polymers, v. 214, p. 152-158, 2019

SPENCE, K. L.; VENDITTI, R. A.; ROJAS, O. J.; PAWLAK, J. J.; HUBBE, M. A Water vapor barrier properties of coated and filled microfibrillated cellulose composites films. Bioresources, v. 6, p. 4370-4388, 2011.

SYVERUD, K.; CHINGA-CARRASCO, G.; TOLEDO, J.; TOLEDO, P. G. A comparative study of Eucalyptus and Pinus radiata pulp fibres as raw materials for production of cellulose nanofibrils. Carbohydrate Polymers, v. 84, n. 3, p. 1033-1038, 2011

SYVERUD, K.; STENIUS, P. Strength and barrier properties of MFC films. Cellulose, v. 16, n. 1, p. 75-85, 2009.

THUAULT, A: DOMENGÈS, B.: HERVAS, I: GOMINA, M. Investigation of the internal structure of flax fibre cell walls by transmission electron microscopy. Cellulose, v. 22, p. 3521-3530, 2015

TONOLI, G. H. D.; HOLTMAN, K. M.; GLENN, G.; FONSECA, A. A.; WOOD, D.; WILLIAMS, T.; SÁ, V. A.; TORRES, L.; KLAMCZYNSKI, A.; ORTS, W. J. Properties of cellulose micro/nanofibers obtained from eucalyptus pulp fiber treated with anaerobic digestate and high shear mixing. Cellulose, v. 23, p. $1239-$ 1256, 2016.

TONOLI, G. H. D.; SANTOS, S. F.; TEIXEIRA, R. S.; SILVA, M. A. P.; LAHR, F. A R.; SILVA, F. H. P.; SAVASTANO JUNIOR, H. Effects of eucalyptus pulp refining on the performance and durability of fibre-cement composites. Journal of Tropical Forest Science, v. 25, n. 3, p. 400-409, 2013.

VIANA, L. C: MUNIZ, G. I. B: MAGALHÃES, W L. E: ANDRADE, A S NISGOSKI, S.; POTULSKI, D. C. Physical and mechanical properties of nanostructed films produced from the unbleached Pinus sp. kraft pulp. Scientia Forestalis, v. 45, n. 116, p. 653-662, 2017

WANG, $\mathrm{H}: \mathrm{LI}, \mathrm{D}$ : YANO $\mathrm{H}$ : ABE, K. Preparation of tough cellulose II nanofibers with high thermal stability from wood. Cellulose, v. 21, p. 1505-1515, 2014

WANG, Q. Q.; ZHU, J. Y.; GLEISNER, R.; KUSTER, T. A.; BAXA, U.; MCNEIL, S E. Morphological development of cellulose fibrils of a bleached eucalyptus pulp by mechanical fibrillation. Cellulose, v. 19, p. 1631-1643, 2012.

WANG, S.; SONG, C.; CHEN, G.; LIU, T. G. J.; ZHANG, B.; TAKEUCHIC S Characteristics and biodegradation properties of poly (3-hydroxybutyrateco-3-hydroxyvalerate)/organophilic montmorillonite (PHBV/OMMT) nanocomposites. Polymer Degradation Stability, v. 87, n. 1, p. 69-76, 2005.

YUNOS, N. S. H. M.; BAHARUDDIN, A. S.; YUNOS, K. F. M.; NAIM, M. N.; NISHIDA, $H$. Physicochemical property changes of oil palm mesocarp fibers treated with high-pressure steam. BioResources, v. 7, n. 4, p. 59835994, 2012.

ZIMMERMANN, M. V. G.; TAÍS, C. T.; ZATTERA, A. J. Influence of the chemical treatment of banana fiber on poly (ethylene-co-vinyl acetate) composites with and without a blowing agent. Polímeros: Ciência e Tecnologia, v. 24, n 1 . p. $58-64,2014$

ZULUAGA, R.; PUTUAUX, J. L.; CRUZ, J.; VÉLEZ, J.; MONDRAGON, I.; GAÑAN, P. Cellulose microfibrils from banana rachis: effect of alkaline treatments on structural and morphological features. Carbohydrate Polymers, v. 76, n. 1, p. 51-59, 2009. 